\title{
KIERUNKI ROZWOJU AGROTURYSTYKI NA OBSZARZE NADBUŻAŃSKIM
}

\author{
Dominik Dąbrowski*, Katarzyna Radwańska**, Janusz Leszek Sokót ${ }^{*}$ \\ Państwowa Szkoła Wyższa im. Papieża Jana Pawła II w Białej Podlaskiej \\ *Wydział Nauk o Zdrowiu i Nauk Społecznych, Zakład Turystyki i Rekreacji \\ Kierownik zakładu: dr Ewelina Niźnikowska \\ ${ }^{* *}$ Wydział Nauk Ekonomicznych i Technicznych, Zakład Rolnictwa \\ Kierownik zakładu: dr inż. Alicja Baranowska
}

\begin{abstract}
Słowa kluczowe: turystyka, gospodarstwa agroturystyczne, dolina Bugu
Key words: tourism, agritourist farms, valley of Bug

JELcode: Q1, P12, Q26, Z32

S y n o p s i s. Dolina rzeki Bug to wyjątkowy obszar na terenie Polski, charakteryzujący się bogatymi walorami zarówno przyrodniczymi, jak i kulturowymi. To również tereny w dużym stopniu rolnicze i nieprzekształcone, a jednocześnie objęte ochroną prawną. W wyniku przeprowadzonych badań wśród właścicieli gospodarstw agroturystycznych 34 gmin usytuowanych na obszarze trzech województw (podlaskiego, lubelskiego i mazowieckiego) w dolinie rzeki Bug stwierdzono, iż atutami wpływającymi w znacznym stopniu na rozwój turystyki na badanym terenie są walory przyrodnicze terenu nadbużańskiego oraz wyjątkowa cisza i spokój, a także dostęp do istniejącej infrastruktury turystycznej. Wskazano również na dużą rolę informacji turystycznej, potrzebę jej popularyzacji (przez wydawanie albumów, katalogów i innych opracowań reklamowych) oraz utrzymania wysokiego standardu prowadzonych usług. Za główną barierę rozwoju agroturystyki uznano brak nawyku w społeczeństwie do wypoczynku weekendowego i sezonowość istniejących ofert.
\end{abstract}

\section{WSTĘP}

Kluczowymi czynnikami sprzyjającymi rozwojowi turystyki wiejskiej są walory przyrodnicze, takie jak: lasy, góry czy zbiorniki wodne [Sokół, Boruch 2011]. Dolina Bugu to obszar niezwykle atrakcyjny pod tym względem. Jest to rzeka o nieuregulowanym korycie, zaliczana do najpiękniejszych nizinnych rzek w Polsce. Wzdłuż jej brzegów można obserwować unikatowe zbiorowiska roślinne oraz rzadkie gatunki zwierząt, przede wszystkim ptaków, które mają tu swoje miejsca lęgowe [Mączka 2008]. Obszar ten szczególnie w odcinku przygranicznym odznacza się niespotykanymi walorami kulturowymi, spowodowanymi zetknięciem się na tym terenie trzech kultur: polskiej, ruskiej i żydowskiej, które bardzo wyraźnie uwidoczniają się w krajobrazie. Na stosunkowo niewielkim obszarze można podziwiać zachowane do dziś 
budowle sakralne: katolickie sanktuarium, prawosławny klasztor, neounicką parafię, żydowską synagogę oraz mahometański mizar. Na tym terenie znajdują się również zabytki architektoniczne, zespoły pałacowo-parkowe oraz dworsko-parkowe, a także obiekty historyczno-wojskowe, które wiążą się z tragiczną historią tego regionu. Częstym obrazkiem, szczególnie na obszarach wiejskich, są również przydrożne kapliczki oraz krzyże łacińskie i prawosławne [Bernat 2014].

Tereny leżące bezpośrednio w sąsiedztwie doliny rzeki Bug mają w zdecydowanej większości charakter nieprzemysłowy. Są to obszary, które wykazują zróżnicowany stopień antropogenizacji, związany przede wszystkim z rolniczą działalnością człowieka. Użytki rolne w gminach nadbużańskich zajmują średnio 64,4\% powierzchni. Wysoki udział użytków rolnych oraz ludności rolniczej przy stosunkowo korzystnych warunkach do produkcji rolnej sprawia, że rolnictwo stanowi na tym obszarze jeden z najważniejszych działów gospodarki. Te czynniki, a także unikalne walory krajobrazowe doliny stwarzają duży potencjał agroturystyczny tego obszaru. Dodatkowym atutem terenów nadbużańskich jest to, iż po stronie polskiej w przeważającej części podlegają one ochronie prawnej. Wiele terenów jest objętych rezerwatami, parkami krajobrazowymi i obszarami chronionego krajobrazu. Dolina Bugu, a przede wszystkim jej dolny odcinek, jest dzięki temu intensywnie wykorzystywana rekreacyjnie [Wojciechowski i in. 2002].

Zdaniem Jana Sikory, podstawową formą usług turystycznych gospodarstw rolniczych jest możliwość udostępnienia gościom pomieszczeń mieszkalnych na cele noclegowe [Sikora 2012]. Oferta gospodarstw może być dużo bardziej atrakcyjna, jeśli dane gospodarstwo prowadzi produkcję rolniczą w systemie ekologicznym, co umożliwia turystom spożywanie produktów pochodzenia roślinnego i zwierzęcego wytwarzanych na miejscu, w naturalny sposób, gwarantujący ich wysoką jakość. Dobrze jest, gdy gospodarstwa są usytuowane na obszarach wartościowych przyrodniczo, z dala od centrów turystycznych [Ziółkowski 2006]. W takich gospodarstwach turysta może w czynny sposób włączać się w prace gospodarskie i obserwować metody produkcji ekologicznej [Ziółkowski 2006, Sokól, Boruch 2011].

Agroturystyka jako forma spędzania wolnego czasu w gospodarstwach rolnych cieszy się rosnącym zainteresowaniem turystów [Zawadka 2015, Jalinik 2016, Sikora 2016] i adresowana jest przede wszystkim do klientów indywidualnych, rodzin lub małych grup turystycznych. Nie wymaga rozbudowanej bazy noclegowej bądź żywieniowej; może z powodzeniem rozwijać się na bazie istniejących zasobów mieszkaniowych gospodarstw rolnych, niewykorzystanych obiektów inwentarskich oraz przestrzeni rekreacyjnej w obrębie gospodarstwa [Sokół 2012].

Agroturystyka i ekoturystyka to formy turystyki wiejskiej mające ze sobą wiele wspólnych cech. Obie są formą aktywnego wypoczynku na obszarach o wyjątkowych walorach przyrodniczych i kulturowych. Różnica między nimi polega przede wszystkim na motywie podróży. Agroturystyka to wypoczynek stacjonarny, o charakterze sielankowym czy wręcz idyllicznym, natomiast ekoturystyka ma na celu czynne odkrywanie i poznawanie otaczającej przyrody oraz kultury [Zaręba 2008].

Coraz częściej rolnictwo konwencjonalne zastępowane jest ekologicznym, w którym rezygnuje się z intensywnej produkcji oraz stosowania środków chemicznych przy jednoczesnym zachowaniu odpowiedniej jakości produktu końcowego [Ziółkowski 2006, Przezbórska 2007]. Rolnictwo ekologiczne nie zagraża bioróżnorodności agro- 
biocenoz i otaczających je ekosystemów, pozwala na zachowanie równowagi w środowisku przyrodniczym, co jest istotne szczególnie na obszarach chronionych i o cennych walorach przyrodniczych i kulturowych [Popławski 2009]. Dodatkowo ten sposób gospodarowania poprawia żyzność i urodzajność gleby, co ma szczególne znaczenie na nadbużańskim terenie, gdzie przeważają gleby niskiej i średniej klasy [Komorowska 2015]. Wytwarzane produkty ekologiczne przyciągają nabywców. Turyści mogą nie tylko obserwować proces produkcji, ale również mogą mieć pewność, że oferowana żywność ma pochodzenie naturalne i jest ekologiczna [Sokół, Kołoszko-Chomentowska 2010].

\section{METODY I MATERIAŁ BADAWCZY}

Zasadniczym celem badań była ocena rozwoju agroturystyki na wiejskich terenach doliny Bugu. Badania empiryczne przeprowadzono w 2018 roku na terenie trzech województw (lubelskiego, podlaskiego, mazowieckiego), w tym w dwunastu powiatach i trzydziestu czterech gminach położonych w bliskim sąsiedztwie doliny rzeki Bug. Do przeprowadzenia badań wykorzystano metodę sondażu diagnostycznego, w ramach której przygotowano internetowy kwestionariusz ankiety wywiadu. Dobór próby badawczej miał charakter celowy. W badaniach uczestniczyło 99 właścicieli gospodarstw agroturystycznych, których gospodarstwa miały status gospodarstwa konwencjonalnego lub ekologicznego bądź znajdowały się w fazie przekształcenia z produkcji konwencjonalnej na ekologiczną. Wszystkie były położone w gminach nadbużańskich.

Materiał opracowano metodami statystycznymi zgodnie $\mathrm{z}$ obowiązującymi w tym względzie zasadami, wykorzystując do tego celu pakiet STATISTICA. Analiza statystyczna to wyniki procentowego rozkładu liczebności, natomiast współzależność pomiędzy zmiennymi badano testem niezależności Chi-kwadrat, a istotność różnic określono przy poziomie $\mathrm{p}<0,05$. Badania były anonimowe, a ich wyniki wykorzystano jedynie do potrzeb naukowych. Oceny dokonano na podstawie opinii właścicieli gospodarstw agroturystycznych, które wyrazili w ankiecie.

\section{WYNIKI BADAŃ}

W badaniach prowadzonych na terenie doliny Bugu, udział wzięło 99 właścicieli gospodarstw agroturystycznych. Liczba gospodarstw w poszczególnych województwach była zbliżona i wynosiła w województwach: lubelskim - 33, podlaskim - 30 oraz w mazowieckim - 36. W przeprowadzonych badaniach 53,5\% ogółu respondentów to kobiety, a 46,5\% mężczyźni. Najczęściej były to osoby powyżej pięćdziesiątego roku życia $(43,4 \%)$ i posiadające wykształcenie wyższe $(54,5 \%)$ lub wykształcenie średnie $(35,4 \%)$.

Najczęściej działalność agroturystyczną prowadzono w gospodarstwach o powierzchni do pięciu hektarów $(41,4 \%)$, znaczna większość korzystała z dopłat do prowadzonej działalności $(65,7 \%)$, a wiodącą w gospodarstwie była produkcja roślinna $(53,5 \%)$. Jednocześnie produkcja rolna przeznaczona była głównie na potrzeby własne $(44,8 \%)$. Spośród ogółu badanych gospodarstw agroturystycznych 23,2\% stanowiły gospodarstwa ekologiczne, których najwięcej było w województwie lubelskim (39,1\%). 
Tabela 1. Charakterystyka właścicieli i gospodarstw agroturystycznych na terenach doliny Bugu $(\mathrm{N}=99)$

\begin{tabular}{|c|c|c|}
\hline \multirow{2}{*}{$\begin{array}{l}\text { Wyszczególnienie } \\
\text { Płeć }\end{array}$} & \multicolumn{2}{|c|}{ Wielkości } \\
\hline & Liczba & $\%$ \\
\hline Mężczyzna & 46 & 46,5 \\
\hline Kobieta & 53 & 53,5 \\
\hline \multicolumn{3}{|c|}{ Wiek } \\
\hline do 30 lat & 10 & 10,1 \\
\hline $31-40$ lat & 25 & 25,3 \\
\hline $41-50$ lat & 21 & 21,2 \\
\hline powyżej 50 lat & 43 & 43,4 \\
\hline \multicolumn{3}{|c|}{ Wykształcenie } \\
\hline Zawodowe & 10 & 10,1 \\
\hline Średnie & 35 & 35,4 \\
\hline Wyższe & 54 & 54,5 \\
\hline \multicolumn{3}{|c|}{ Wielkość gospodarstwa } \\
\hline do 5 ha & 41 & 41,4 \\
\hline $6-10$ ha & 22 & 22,2 \\
\hline $11-20$ ha & 22 & 22,2 \\
\hline $21-50$ ha & 8 & 8,1 \\
\hline powyżej 50 ha & 6 & 6,1 \\
\hline \multicolumn{3}{|c|}{ Korzystanie z dopłat } \\
\hline Tak & 65 & 65,7 \\
\hline $\mathrm{Nie}$ & 34 & 34,3 \\
\hline \multicolumn{3}{|c|}{ Ukierunkowanie gospodarstwa } \\
\hline Produkcja roślinna & 53 & 53,5 \\
\hline Produkcja zwierzęca & 12 & 12,1 \\
\hline Produkcja roślinna i zwierzęca & 34 & 34,3 \\
\hline \multicolumn{3}{|c|}{ System produkcji rolnej } \\
\hline Produkcja ekologiczna & 23 & 23,1 \\
\hline Produkcja konwencjonalna & 76 & 76,9 \\
\hline
\end{tabular}

Źródło: badania własne.

Pozostałe $76,8 \%$ to były gospodarstwa z konwencjonalnym systemem produkcji rolniczej, których najwięcej odnotowano na terenie województwa mazowieckiego (39,5\%). Szczegółowe informacje zawarto w tabeli 1.

Wyniki badań zestawione w tabeli 2. wskazują, iż najważniejszymi motywami właścicieli prowadzących działalność agroturystyczną były możliwość poprawy budżetu domowego $(40,4 \%)$ oraz realizacja hobby i własnych potrzeb $\mathrm{w}$ dziedzinie turystycznej (36,4\%). Około 60\% badanych gospodarstw działalność agroturystyczną prowadziło od ponad siedmiu lat. Jednocześnie $59,6 \%$ posiadało do dziesięciu miejsc noclegowych. Wśród odwiedzających turyści indywidualni stanowili 33,2\%, grupy zawodowe realizujące zwykle szkolenia lub imprezy integracyjne i inne $-25,1 \%$ oraz rodziny $\mathrm{z}$ dziećmi $-24,7 \%$. W ofercie dla turystów była możliwość zakupu produktów pochodzących z własnego gospodarstwa, najczęściej dotyczyło to owoców i warzyw $(61,6 \%)$ i produktów przetwarzanych $(57,1 \%)$, a także w mniejszej części pieczywa i ciasta $(35,7 \%)$. 
Tabela 2. Cechy działalności turystycznej gospodarstw $(\mathrm{N}=99)$

\begin{tabular}{|c|c|c|}
\hline \multirow{2}{*}{ Główny motyw prowadzenia działalności agroturystycznej } & \multicolumn{2}{|c|}{ Wielkości } \\
\hline & Liczba & $\%$ \\
\hline Możliwości poprawy budżetu domowego, cel typowo zarobkowy & 40 & 40,4 \\
\hline Wykorzystanie istniejącej bazy noclegowej & 12 & 12,1 \\
\hline Niska rentowność gospodarstw rolnych & 2 & 2,0 \\
\hline Dodatkowa chęć sprzedaży produktów rolniczych & 9 & 9,1 \\
\hline Realizacja hobby, realizacja własnych potrzeb w dziedzinie turystycznej & 36 & 36,4 \\
\hline \multicolumn{3}{|l|}{ Liczba miejsc noclegowych w gospodarstwie } \\
\hline$<10$ osób & 59 & 59,6 \\
\hline $11-20$ osób & 28 & 28,3 \\
\hline $21-30$ osób & 9 & 9,1 \\
\hline$>31$ osób & 3 & 3,0 \\
\hline \multicolumn{3}{|l|}{ Klasyfikacja gości przyjmowanych w gospodarstwie } \\
\hline Zielone szkoły i grupy kolonijne & 12 & 7,7 \\
\hline Turyści indywidualni & 90 & 33,2 \\
\hline Rodziny z dziećmi & 67 & 24,7 \\
\hline Grupy zawodowe (szkolenia, wyjazdy integracyjne, okolicznościowe) & 68 & 25,1 \\
\hline Turyści zagraniczni & 34 & 12,55 \\
\hline \multicolumn{3}{|l|}{ Okres prowadzenia działalności agroturystycznej } \\
\hline 1-3 lat & 9 & 9,1 \\
\hline 4-7 lat & 32 & 32,3 \\
\hline ponad 7 lat & 58 & 58,6 \\
\hline \multicolumn{3}{|l|}{ Oferowane produkty dla turystów } \\
\hline Owoce i warzywa & 61 & 61,6 \\
\hline Przetwory owocowo-warzywne & 56 & 57,1 \\
\hline Mleko i jego przetwory & 21 & 21,4 \\
\hline Jaja & 33 & 33,7 \\
\hline Pieczywo/ciasta & 35 & 35,7 \\
\hline Produkty mięsne & 11 & 11,2 \\
\hline Ryby & 11 & 11,2 \\
\hline Inne & 20 & 20,2 \\
\hline
\end{tabular}

Źródło: badania własne.

Rozwój agroturystyki uwarunkowany jest różnorodnymi czynnikami. Ankietowani właściciele gospodarstw agroturystycznych (tabela 3.) wskazywali najczęściej na czynniki określające walory przyrodnicze terenu nadbużańskiego (91,9\%), ciszę i spokój $(80,8 \%)$, a także dostęp do szlaków turystycznych $(70,7 \%)$. Najrzadziej wskazywano możliwość korzystania z produktów ekologicznych $(25,2 \%)$.

W zakresie czynników rozwoju agroturystyki w ujęciu wojewódzkim największe różnice odnotowano w opiniach dotyczących chęci poznania kultury oraz tradycji i obyczajów, w odniesieniu do możliwości korzystania z kąpieliska przy rzece Bug oraz w poziomie atrakcji i oczekiwaniu wysokich standardów świadczonych usług $(\mathrm{p}<0,05)$. Walory przyrodnicze zostały docenione przez większość respondentów, w tym wszystkich respondentów w województwie podlaskim.

Najczęściej wskazywane działania przyczyniające się do zwiększenia popularności turystyki w regionie $\mathrm{w}$ opinii właścicieli gospodarstw agroturystycznych to odpowiednia informacja turystyczna $(91,6 \%)$, wydawanie albumów, katalogów i innych opracowań 
Tabela 3. Czynniki rozwoju agroturystyki w opinii właścicieli gospodarstw według województw $(\mathrm{N}=99)$

\begin{tabular}{|c|c|c|c|c|c|c|c|c|c|c|}
\hline \multirow{3}{*}{$\begin{array}{l}\text { Czynniki rozwoju agrotu- } \\
\text { rystyki }\end{array}$} & \multirow{2}{*}{\multicolumn{2}{|c|}{ ogółem }} & \multicolumn{6}{|c|}{ województwo } & \multirow{3}{*}{$\mathrm{Chi}^{2}$} & \multirow{3}{*}{$\mathrm{p}$} \\
\hline & & & \multicolumn{2}{|c|}{ lubelskie } & \multicolumn{2}{|c|}{ podlaskie } & \multicolumn{2}{|c|}{ mazowieckie } & & \\
\hline & $\mathrm{n}$ & $\%$ & $\mathrm{n}$ & $\%$ & $\mathrm{n}$ & $\%$ & $\mathrm{n}$ & $\%$ & & \\
\hline Walory przyrodnicze & 91 & 91,9 & 30 & 90,9 & 30 & 100 & 31 & 86,1 & 4,318 & 0,115 \\
\hline Walory kulturowe & 55 & 55,5 & 19 & 57,6 & 19 & 63,3 & 17 & 47,2 & 1,802 & 0,406 \\
\hline Cisza, spokój & 80 & 80,8 & 26 & 78,8 & 24 & 80 & 30 & 83,3 & 0,247 & 0,883 \\
\hline Rzeka z kąpieliskiem & 49 & 49,5 & 10 & 30,3 & 19 & 63,3 & 20 & 55,6 & 7,689 & $0,021 *$ \\
\hline Szlaki turystyczne & 70 & 70,7 & 26 & 78,8 & 22 & 73,3 & 22 & 61,1 & 2,741 & 0,254 \\
\hline Imprezy kulturalne & 45 & 45,5 & 13 & 39,4 & 19 & 63,3 & 13 & 36,1 & 5,624 & 0,06 \\
\hline $\begin{array}{l}\text { Chęć poznania kultury, tra- } \\
\text { dycji, obyczajów }\end{array}$ & 58 & 58,6 & 17 & 51,5 & 25 & 83,3 & 16 & 44,4 & 11,219 & $\mathbf{0 , 0 0 3 *}$ \\
\hline $\begin{array}{l}\text { Atrakcyjność i wysoki stan- } \\
\text { dard usług }\end{array}$ & 41 & 41,4 & 13 & 39,4 & 18 & 60 & 10 & 27,8 & 7,086 & $0,029 *$ \\
\hline $\begin{array}{l}\text { Korzystanie z produktów } \\
\text { ekologicznych }\end{array}$ & 25 & 25,2 & 12 & 36,4 & 5 & 16,7 & 8 & 22,2 & 3,505 & 0,173 \\
\hline
\end{tabular}

* poziom istotności $\mathrm{p}<0,05$

Źródło: badania własne.

reklamowych $(57,7 \%)$ oraz dbałość o utrzymanie wysokiego standardu usług i ich atrakcyjność $(54,1 \%)$. Szczegółowo zaprezentowano to w tabeli 4.

Można wskazać, iż prawie jednomyślnie we wszystkich województwach określono znaczenie właściwej informacji turystycznej jako ważnego działania przyczyniającego się do zwiększenia popularności turystyki (tabela 4.). W odniesieniu do pozostałych dzia-

Tabela 4. Ocena działań przyczyniających się do zwiększenia popularności turystyki w regionie według województw $(\mathrm{N}=99)$

\begin{tabular}{|c|c|c|c|c|c|c|c|c|c|c|}
\hline \multirow{3}{*}{ Rodzaj działania } & \multirow{2}{*}{\multicolumn{2}{|c|}{ ogółem }} & \multicolumn{6}{|c|}{ województwo } & \multirow{3}{*}{$\mathrm{Chi}^{2}$} & \multirow{3}{*}{$\mathrm{p}$} \\
\hline & & & \multicolumn{2}{|c|}{ lubelskie } & \multicolumn{2}{|c|}{ podlaskie } & \multicolumn{2}{|c|}{ mazowieckie } & & \\
\hline & $\mathrm{n}$ & $\%$ & $\mathrm{n}$ & $\%$ & $\mathrm{n}$ & $\%$ & $\mathrm{n}$ & $\%$ & & \\
\hline Modernizacja i oświetlenie dróg & 38 & 38,4 & 10 & 30,3 & 15 & 50 & 13 & 36,1 & 2,701 & 0,259 \\
\hline Poprawa dostępu do Internetu & 36 & 36,4 & 7 & 21,2 & 15 & 50 & 14 & 38,9 & 5,784 & 0,055 \\
\hline Rozwój usług, handlu, gastronomii & 42 & 42,4 & 11 & 33,3 & 17 & 56,7 & 14 & 38,9 & 3,792 & 0,15 \\
\hline $\begin{array}{l}\text { Odpowiednia informacja tury- } \\
\text { styczna }\end{array}$ & 87 & 91,6 & 30 & 93,7 & 27 & 90 & 30 & 90,9 & 0,312 & 0,855 \\
\hline Zmiana mentalności mieszkańców & 46 & 46,4 & 12 & 36,4 & 19 & 63,3 & 15 & 41,7 & 5,118 & 0,077 \\
\hline $\begin{array}{l}\text { Wysoki standard usług i ich atrak- } \\
\text { cyjność }\end{array}$ & 53 & 54,1 & 13 & 39,4 & 19 & 63,3 & 21 & 60 & 4,394 & 0,111 \\
\hline $\begin{array}{l}\text { Wydawanie albumów, katalogów } \\
\text { i innych opracowań powiązanych } \\
\text { z reklamą miejsc atrakcyjnych } \\
\text { turystycznie }\end{array}$ & 56 & 57,7 & 22 & 70,9 & 19 & 63,3 & 15 & 41,7 & 6,418 & $0,040 *$ \\
\hline
\end{tabular}

* poziom istotności $\mathrm{p}<0,05$ 
łań odnotowano większe zróżnicowanie przestrzenne opinii respondentów. Dla opinii respondentów według województw w odniesieniu do znaczenia opracowywania albumów lub innych elementów reklamowych wystąpiła różnica istotna statystycznie $(\mathrm{p}=0,04)$ z wyraźną przewagą opinii właścicieli gospodarstw w województwie lubelskim w porównaniu do opinii respondentów z terenu województwa mazowieckiego.

Wskazywane przez właścicieli gospodarstw bariery w rozwoju działalności eko-agroturystycznej (tabela 5.) to brak własnych środków finansowych $(59,6 \%)$, a także obawa przed zainwestowaniem środków $(58,6 \%)$. Najrzadziej wskazywaną barierą była dostępność odpowiednio wykształconej kadry w branży turystycznej (14,3\%).

Tabela 5. Ocena barier rozwoju działalności eko-agroturystycznej z uwzględnieniem podziału na województwa $(\mathrm{N}=99)$

\begin{tabular}{|c|c|c|c|c|c|c|c|c|c|c|}
\hline \multirow{3}{*}{$\begin{array}{l}\text { Rodzaj bariery rozwoju } \\
\text { działalności eko-agroturystycznej }\end{array}$} & \multicolumn{8}{|c|}{ województwo } & \multirow{3}{*}{$\mathrm{Chi}^{2}$} & \multirow{3}{*}{$\mathrm{p}$} \\
\hline & \multicolumn{2}{|c|}{ ogółem } & \multicolumn{2}{|c|}{ lubelskie } & \multicolumn{2}{|c|}{ podlaskie } & \multicolumn{2}{|c|}{ mazowieckie } & & \\
\hline & $\mathrm{n}$ & $\%$ & $\mathrm{n}$ & $\%$ & $\mathrm{n}$ & $\%$ & $\mathrm{n}$ & $\%$ & & \\
\hline $\begin{array}{l}\text { Brak własnych środków } \\
\text { finansowych }\end{array}$ & 59 & 59,6 & 23 & 69,7 & 18 & 60 & 18 & 50 & 2,777 & 0,249 \\
\hline $\begin{array}{l}\text { Trudny dostęp do środków } \\
\text { pomocowych }\end{array}$ & 43 & 43,4 & 13 & 39,4 & 12 & 40 & 18 & 50 & 0,994 & 0,608 \\
\hline Bariera w kredytowaniu & 22 & 22,2 & 6 & 18,2 & 7 & 23,3 & 9 & 25 & 0,494 & 0,781 \\
\hline Brak pomysłu i chęci na biznes & 40 & 40,4 & 21 & 63,6 & 10 & 33,3 & 9 & 25 & 11,567 & $0,003 *$ \\
\hline $\begin{array}{l}\text { Obawa przed zainwestowaniem } \\
\text { środków }\end{array}$ & 58 & 58,6 & 20 & 60,6 & 18 & 60 & 20 & 55,6 & 0,216 & 0,898 \\
\hline $\begin{array}{l}\text { Brak wykształconej kadry } \\
\text { w branży turystycznej i trudności } \\
\text { w jej pozyskaniu }\end{array}$ & 14 & 14,3 & 2 & 6,1 & 3 & 10,3 & 9 & 25 & 5,566 & 0,062 \\
\hline $\begin{array}{l}\text { Niski stopień współpracy między } \\
\text { gospodarstwami }\end{array}$ & 40 & 40,4 & 14 & 42,4 & 15 & 50 & 11 & 30,6 & 2,653 & 0,262 \\
\hline $\begin{array}{l}\text { Brak dobrego doradztwa } \\
\text { i szkoleń }\end{array}$ & 44 & 44,4 & 19 & 57,6 & 11 & 36,7 & 14 & 38,9 & 3,489 & 0,174 \\
\hline
\end{tabular}

* poziom istotności $\mathrm{p}<0,05$

Źródło: badania własne.

Z danych zestawionych w tabeli 5. wynika, że opinie właścicieli gospodarstw agroturystycznych odnośnie barier były zróżnicowane w ujęciu wojewódzkim. Dotyczyło to bariery odnoszącej się do braku pomysłu i chęci na biznes $(\mathrm{p}=0,003)$. Najczęściej była ona wskazywana przez właścicieli gospodarstw w województwie lubelskim (63,6\%), a najrzadziej przez ankietowanych z województwa mazowieckiego (25,0\%). Dosyć wyraźne zróżnicowanie w ujęciu regionalnym odnotowano w odniesieniu do dostępności własnych środków finansowych lub wręcz ich braku. W opinii respondentów z gospodarstw położonych w województwie lubelskim problem ten był zgłaszany bardzo często, bowiem jego istnienie potwierdziło prawie $70 \%$ respondentów, natomiast w województwie mazowieckim wskazał go tylko co drugi $(50,0 \%)$ ankietowany. Najmniejsze zróżnicowanie udziału respondentów według województw wystąpiło w odniesieniu do opinii 
dotyczącej obawy przed ryzykiem zainwestowania środków finansowych (udział mieścił się w przedziale od $56 \%$ do $61 \%$ ).

Bariery ograniczające lub też uniemożliwiające rozwój turystyki na wiejskich terenach doliny Bugu, a tym samym ograniczające rozwój działalności agroturystycznej zestawiono w tabeli 6 . Niską częstotliwość przyjazdów, a tym samym ich udziału w formach turystyki wiejskiej, upatrywano w braku nawyków do wypoczynku weekendowego $(64,6 \%)$, a w dalszej kolejności: w sezonowości ofert $(62,6 \%)$ i małej popularności tej formy wypoczynku $(62,6 \%)$.

Tabela 6. Ocena barier rozwoju turystyki wiejskiej według województw $(\mathrm{N}=99)$

\begin{tabular}{|c|c|c|c|c|c|c|c|c|c|c|}
\hline \multirow{3}{*}{$\begin{array}{l}\text { Bariery rozwoju turystyki } \\
\text { wiejskiej }\end{array}$} & \multicolumn{8}{|c|}{ województwo } & \multirow{3}{*}{$\mathrm{Chi}^{2}$} & \multirow{3}{*}{$\mathrm{p}$} \\
\hline & \multicolumn{2}{|c|}{ ogółem } & \multicolumn{2}{|c|}{ lubelskie } & \multicolumn{2}{|c|}{ podlaskie } & \multicolumn{2}{|c|}{ mazowieckie } & & \\
\hline & $\mathrm{n}$ & $\%$ & $\mathrm{n}$ & $\%$ & $\mathrm{n}$ & $\%$ & $\mathrm{n}$ & $\%$ & & \\
\hline $\begin{array}{l}\text { Brak nawyku wypoczynku } \\
\text { weekendowego }\end{array}$ & 64 & 64,6 & 21 & 63,6 & 21 & 70 & 22 & 61,1 & 0,587 & 0,745 \\
\hline $\begin{array}{l}\text { Brak zorganizowanych atrakcji } \\
\text { wypoczynku weekendowego }\end{array}$ & 39 & 39,4 & 14 & 42,4 & 13 & 43,3 & 12 & 33,3 & 0,876 & 0,645 \\
\hline Sezonowość ofert & 62 & 62,6 & 25 & 75,8 & 16 & 53,3 & 21 & 58,3 & 3,821 & 0,148 \\
\hline $\begin{array}{l}\text { Brak odpowiedniej } \\
\text { infrastruktury }\end{array}$ & 40 & 40,4 & 14 & 42,4 & 15 & 50 & 11 & 30,6 & 2,653 & 0,265 \\
\hline $\begin{array}{l}\text { Niska popularność turystyki } \\
\text { wiejskiej }\end{array}$ & 62 & 62,6 & 20 & 60,6 & 21 & 70 & 21 & 60,6 & 1,037 & 0,595 \\
\hline Słaba informacja i reklama & 52 & 52,5 & 17 & 53,1 & 13 & 43,3 & 22 & 61,1 & 2,076 & 0,354 \\
\hline Mała atrakcyjność oferty & 34 & 34,3 & 17 & 51,5 & 8 & 26,7 & 9 & 25 & 6,493 & $0,038 *$ \\
\hline
\end{tabular}

* poziom istotności $\mathrm{p}<0,05$

Źródło: badania własne.

W odniesieniu do barier w ujęciu województw stwierdzono różnice opinii respondentów jedynie $\mathrm{w}$ odniesieniu do małej atrakcyjności ofert $(\mathrm{p}<0,05)$. Pozostałe opinie respondentów nie różniły się wyraźnie w ujęciu przestrzennym, chociaż odsetek osób wskazujących poszczególne bariery był odmienny. Problem sezonowości ofert częściej wskazywali ankietowani z województwa lubelskiego (75,8\%), zaś niska popularność turystyki wiejskiej (70\%) oraz brak nawyku wypoczynku weekendowego (70\%) to opinie częściej pojawiające się u respondentów w województwie podlaskim. Natomiast niewystarczający poziom informacji i słabą reklamę jako znaczącą barierę w rozwoju turystyki wiejskiej odnotowano częściej w opiniach właścicieli gospodarstw agroturystycznych w województwie mazowieckim $(61,1 \%)$.

\section{PODSUMOWANIE}

Jako główne atuty regionu, które mają wpływ na rozwój turystyki wiejskiej i doskonale wpisują się w jej nurt, respondenci wskazywali najczęściej czynniki określające walory przyrodnicze terenu nadbużańskiego, ciszę i spokój, a także dostęp do szlaków turystycznych. W odniesieniu do czynników rozpatrywanych w ujęciu wojewódzkim 
największe różnice w opiniach właścicieli gospodarstw agroturystycznych dotyczyły chęci poznawania kultury oraz tradycji i obyczajów przez turystów oraz dostępności do rzeki Bug i kąpieliska, a także poziomie atrakcji i standardach świadczonych usług.

W wyniku przeprowadzonych badań wykazano, iż najważniejszym motywem wśród właścicieli prowadzących działalność agroturystyczną była możliwość poprawy budżetu domowego, realizacja hobby, realizacja własnych potrzeb w dziedzinie turystycznej.

W zakresie działań przyczyniających się do zwiększenia popularności turystyki w regionie, najczęściej podkreślono rolę informacji turystycznej, duże znaczenie wydawania albumów, katalogów i innych opracowań reklamowych oraz utrzymanie wysokiego standardu usług i dbałość o ich atrakcyjność.

Wymienianymi barierami rozwoju działalności eko-agroturystycznej były brak własnych środków finansowych, a także obawa przed niewłaściwym zainwestowaniem tych środków. Barierami ograniczającymi lub też uniemożliwiającymi rozwój turystyki na wiejskich terenach doliny Bugu, a tym samym powodami ograniczenia działalności agroturystycznej, były brak nawyków do wypoczynku weekendowego, a w dalszej kolejności sezonowość ofert i mała popularność tej formy wypoczynku.

\section{LITERATURA}

Bernat Sebastian 2014: Walory, zagrożenia i ochrona krajobrazu przygranicznego odcinka doliny Bugu, „Problemy Ekologii Krajobrazu” 26, 257-269.

Jalinik Mikołaj 2016: Nazewnictwo w agroturystyce [w] Turystyka wiejska. Cz. II. Ekonomiczny wymiar turystyki wiejskiej, Anna Jęczmyk, Jarosław Uglis, Magdalena Maćkowiak (red.), Wydawnictwo Wieś Jutra Sp. z o.o., Warszawa, 63-70.

Komorowska Dorota 2015: Znaczenie rolnictwa ekologicznego w Polsce, „Roczniki Naukowe Stowarzyszenia Ekonomistów Rolnictwa i Agrobiznesu" 17(2), 119-126.

Mączka Dorota 2008: Walory turystyczno-krajoznawcze doliny Bugu na przykładzie gmin nadbużańskich poludniowego Podlasia [w] Komercjalizm turystyki kulturowej, Mieczysław K. Leniartek (red.), Wydawnictwo Wyższej Szkoły Zarządzania, Wrocław, 51-59.

Popławski Łukasz 2009: Gospodarstwa agroturystyczne, ekoagroturystyczne i ekologiczne jako czynnik rozwoju turystyki na obszarach chronionych województwa świętokrzyskiego, „Zeszyty Naukowe Małopolskiej Wyższej Szkoły Ekonomicznej w Tarnowie”, 3 (14), 139-152.

Przezbórska Lucyna 2007: Determinanty rozwoju agroturystyki w Polsce (na przykładzie wybranych regionów), „Acta Scientiarum Polonorum. Oeconomia” (2), 113-121.

SikoraJan2012:Agroturystyka.Przedsiębiorczośćnaobszarachwiejskich, Wyd.C.H.Beck, Warszawa, s. 311.

Sikora Jan 2016: Edukacja w agroturystyce [w] Turystyka wiejska. Cz. I. Zagadnienia ekonomiczne i marketingowe, Anna Jęczmyk, Jarosław Uglis, Magdalena Maćkowiak (red.), Wydawnictwo Wieś Jutra Sp. z o.o., Warszawa, 9-18.

Sokół Janusz Leszek 2012: Działalność gospodarstw agroturystycznych na obszarze Narwiańskiego Parku Narodowego w ocenie turystów i ich nowe wyzwania, „Ekonomia i Zarządzanie”, t. 4 , nr 3, 118-128. 
Sokół Janusz Leszek, Boruch Jacek 2011: Ekologizacja gospodarstw agroturystycznych w powiecie biatostockim, „Ekonomia i Zarządzanie” z. 3, 95-112.

Sokół Janusz Leszek, Kołoszko-Chomentowska Zofia 2010: Produkty zwierzęce jako atrakcja w gospodarstwach agroturystycznych, ,Economy and Management” 2 (3), 137-146

Wojciechowski Krzysztof Hubert, Bernat Sebastian., Czubla Paweł, Janicki Radosław 2002: Elementy zagospodarowania dorzecza istotne dla walorów przyrodniczych doliny Bugu [w] Korytarz ekologiczny doliny Bugu. Stan - Zagrożenia - Ochrona, Andrzej Dombrowski, Zygmunt Głowacki, Wojciech Jakubowski, Ivan Kovalchuk, Zdzisław Michalczyk, Michail Nikiforov, Wojciech Szwajgier, Krzysztof Hubert Wojciechowski (red.). Fundacja IUCN Poland, Warszawa 456-462.

Zaręba Dominika 2008: Ekoturystyka. Wyzwania i nadzieje, Wydawnictwo Naukowe PWN, Warszawa, s. 175.

Zawadka Jan 2015: Możliwości finansowania przedsięwzięć z zakresu turystyki wiejskiej w perspektywie 2014-2020 [w] Innowacyjność w turystyce wiejskiej a nowe możliwości zatrudnienia na obszarach wiejskich, Wioletta Kamińska (red.), Studia KPZK PAN, t. CLXXIII, Warszawa, 279-289.

Ziółkowski Bożydar 2006: Rolnictwo ekologiczne a turystyka wiejska - próba modelowego ujęcia wzajemnych zależności, ,Journal of Research and Applications in Agricultural Engineering", Vol. 51(2), 224-229.

\title{
Dominik Dąrowski, Katarzyna Radwańska, Janusz Leszek Sokót
}

\section{DIRECTIONS OF GROWTH OF AGRO TOURISM IN THE NADBUŻAŃSKI REGION}

\begin{abstract}
Summary
Valley of the Bug River is a unique area within the territory of Poland, characterized by rich natural and cultural values. These areas are of agricultural and undeveloped nature to a large degree, while at the same time being covered by legal protection. As a result of the conducted studies among agricultural land owners from 34 communes located in the territory of three provinces (podlaskie, lubelskie and mazowieckie) within the valley of Bug, it was noted that the advantages which largely impact the development of tourism in the area are the natural values of the area and a unique silence and peace, as well as access to the existing touristic infrastructure. Significant role of tourist information as well as the necessity to popularize it were also indicated - through issuing albums, catalogues and other commercial materials and maintainable of high standard of carried out services. The main growth obstacle for agro-tourism is the lack of habit in the society for weekend rest and seasonality of the existing offers.
\end{abstract}

Źródło finansowania badań: środki na działalność statutową Wydział Nauk o Zdrowiu i Nauk Społecznych, Katedra Kultury Fizycznej i Fizjoterapii, Zakład Turystyki i Rekreacji. Państwowa Szkoła Wyższa im. Papieża Jana Pawła II w Białej Podlaskiej. Nr S/10/17 pt. „Ekologizacja rolnictwa a rozwój agroturystyki na obszarach przygranicznych Polski wschodniej”. 
Adres do korespondencji: prof. dr hab. Leszek Janusz Sokół

dr Dominik Dąbrowski (orcid: 0000-0002-3284-9338) Wydział Nauk o Zdrowiu i Nauk Społecznych, Zakład Turystyki i Rekreacji dr inż. Katarzyna Radwańska (orcid: 0000-0003-3496-4281)

Wydział Nauk Ekonomicznych i Technicznych, Zakład Rolnictwa Państwowa Szkoła Wyższa im. Papieża Jana Pawła II w Białej Podlaskiej ul. Sidorska 95/97 21-500 Biała Podlaska janusz.1.sokol@gmail.com d.dabrowski@dydaktyka.pswbp.pl katarzyna.radwanska@yahoo.com 